\title{
RENEGOTIATION: PRO AND CON
}

\author{
Hult LAWRENCE WILSON*
}

"Hither came Jack Spicer and talked of Exchequer matters and how the Lord Treasurer hath now ordered all monies to be brought into the Exchequer, and hath settled the King's revenues and given every general expense proper assignments; to the Navy $£ 200,000$ and odde. He also told me of the vast trade of the goldsmiths in supplying the King with money at dear rates." Pepys's Diary, December 29, I662.

\section{INTRODUCrION}

The problem of economical procurement of the weapons of war is not new. The recurrence of war merely presents the question in new dress. Jack Spicer and the inimitable Pepys may have thought they were conducting a sprightly and unique discussion. But others had argued such matters previously, and the discussion continues unabated today. There may be novelty in the modern note, however. If there is, it is in connection with the procedure which is labelled "renegotiation."

True, renegotiation is not entirely new. The history of states whose power was embodied in autocratic sovereigns is replete with instances of ex post facto adjustments of loans, for example. At times the lender was put off with promises of one kind or another, again he received a monopoly or a grant instead of the repayment of gold-and sometimes he was "liquidated." These various policies might be called "renegotiation" of a sort. Renegotiation on such a level would be no novelty. But the faith which the citizen placed in the stability of state obligations had latterly grown to such stature (almost one of the "folkways" of modern business) that any change in the nature of such obligation, such as renegotiation, would result in immediate protest.

When one of the members of Congress says:

"... there is no such thing as a contract with the Government any more. The businessman is obligated to the Government, but the Government is not obligated to him. You don't need a law to renegotiate. This is just a play on words. That implies mutual consent. Anybody can amend a contract by mutual consent. This isn't renegotiation. This is price adjustment, what you really call it, but there is no contract with the Government any more, is there?"1

- A.B., I922, Upsala; J.D., I928, New York University. Member of New York and Federal Bars; lecturer in government contracts, 1942, Pace Institute; special counsel, New York State Insurance Department in Norway, r937; Production Controls Analyst, Washington office, Research Institute of America.

${ }^{2}$ Hearings before Committee on Naval Affairs purstuant to H. Res. 30, 78 th Cong., Ist Sess. (1943) Vol. 2, 5r7-8. 
he is giving voice to the fear, to the almost visible shiver that runs through the body of business at the slightest whisper that the days of autocratic sovereignty vis-a-vis business might return.

Two observations may be made at this point. First, business and government are involved in a confusion of frames of reference. Renegotiation, its advocates have sometimes insisted, is identical with economical procurement; more, it is the only method of such procurement. Frequently the opponents of the statute have permitted themselves to be taken in by this assumption. Renegotiation is but one of the means of economical procurement-there are others.

That renegotiation is not the only method by which excessive profits may be recaptured is evident from the testimony of the former Chairman of the War Department Price Adjustment Board before the Ways and Means Committee:

"In the last 25 years, there have been no less than 170 bills introduced into the Congress for the elimination and control of war profits."

Second, it would appear that semanticism had achieved a triumph through passage of the renegotiation law. The principle of multiple definition had been applied-and the public had accepted "renegotiation" where it might have rejected "price adjustment."

Definition of "negotiation" is normally given as "deliberation, discussion, or conference upon the terms of a proposed agreement; the act of settling or arranging the terms and conditions of a bargain, sale, or other business transaction."3

In the light of the definition it cannot be gainsaid that war contracts, in the main, were "negotiated." Agreement may not come so readily on the proposition that the proceeding termed "re-negotiation" is anything like a second negotiation, deliberation, discussion or conference upon the terms of a proposed agreement, or arranging terms of a bargain, sale, or other business transaction.

Certain quarters would more probably claim that the correct term should have been "re-dictation." This, again, would be incorrect, since in the vast majority of cases, the original contract was not dictated, but negotiated. The shift in meaning, apparent through the use of the foregoing examples, evidences the fundamental disagreement between the affirmative and negative side of the question of renegotiation.

Having called attention to these two areas of confusion, the discussion of renegotiation's pros and cons will continue on the assumptions: (I) that renegotiation is not economical procurement in its entirety; (2) that renegotiation must be accepted as descriptive of the methodology used, regardless of opinion as to its definition.

On two points there is agreement: ( $x$ ) the immorality of excessive profits; (2) the ability of the price adjustment boards. As to the first, it would be a hardy individual indeed who would attempt the position that excessive war profits should not be

\footnotetext{
${ }^{2}$ Hearings before Committee on Ways and Means on $H . R .2324,2698$ and 3015, 78th Cong., Ist Sess. (I943) 3, September 9, I943.

${ }^{3}$ Black, Law Dictionary.
} 
avoided. The witnesses at the present and prior Congressional hearings were unanimous on this point. As well argue against the tenets of the Lord's Prayer. It might be that some peace advocate should have advanced an argument: Since war itself is economically wasteful, perhaps war procurement should be as wasteful as possible, because only through a world-wide acceptance of the total economic loss which attends war, would we arrive at possibilities of continued world peace. But no such argument was presented.

As to the second: the efficiency and the fairness of the members of the price adjustment boards, their ability and background, have been fully recognized. With over fifty of such boards in the various departments and agencies, the fact that such outstanding groups of business men can be brought into work which for them involves a break in their normal working careers speaks most highly for the determined efforts of the directors of the policy in government to provide as equitable procedure as possible. In considering the work of the armed forces on renegotiation, it should be remembered that any one of 22,000 contracting officers, at one time or another, might be called in to handle certain aspects of renegotiation.

On the Navy Department Board sits a partner of one of the outstanding public accounting firms in the country; a president of a leading investment banking house; an outstanding attorney; other prominent accountants, lawyers, engineers and industrialists. Similar prominence is evident in the membership of other boards. These men know business and its problems, they are not theorists. They give of their years of experience in a conscientious effort to reduce the cost of war.

Because renegotiation is so novel in conception and so recent in operation, because it touches both the advocates of free enterprise and government control to the quick, the writer has found in the utterances of the actors in the drama as played before various Congressional committees the most vivid attacks and defenses. In presenting the pros and cons, therefore, in two sections of this article, numerous quotations will be given. Indulgence of readers who are not overly fond of reading "chamber drama" is asked. At the same time assurance is given that no substitute statements could be as vital as those spoken words reported in the hearings of the Congressional committees. The Jack Spicers and Samuel Pepys' of r943 have devoted time, ingenuity, sincerity and no small amount of heat to this battle.

Treatment of the pros and cons involved in the debate over renegotiation procedure will be grouped under the following headings: War Profits Controls in Other Countries, Arguments for Renegotiation, Arguments Against Renegotiation, Striking the Balance. ${ }^{4}$

\footnotetext{
'Discussion of economic and juridical aspects of renegotiation are to be found in a number of recent law reviews: Steadman, Renegotiation of War Contracts (1943) 42 Mrcu. L. Rev. 1; Judson, The Renegotiation of War Contracts (1943) 10 U. of CHr. L. Rev. 193; LaBrum, Some Recent Developments in Renegotiation of War Contracts (1943) 91 U. of PA. L. Rev. 7r4; Withrow, The Control of War Profits in the United States and Canada (1942) 91 U. of PA. L. REv. x94; Notes (1943) II Geo. WASH. L. Rev. 227; (1942) 37 Ill. L. Rev. 155; (1942) 16 So. CaLIR. L. Rev. 31. Also, Patterson, Renegotiation: Wihat It Is: What It Does: How It Works (Jan. 1943) Dun's Revizw, 8.
} 


\section{War Profits Controls in Other Countries}

What is done about the profits picture in Britain, in Canada, in Germany, in Russia? Here we may find in four countries-two with a politico-economic system close to ours, one with a system admitting some private profit but asserting state supremacy, one with a system generally denying private profit-interesting comparisons.

I. War Profits Control in Britain. The Parliamentary Select Committee on National Expenditure in its Fourth Report ${ }^{5}$ comments on government procurement procedure in the following words:

"It has been quite apparent, for instance, that the departmental officers who have propounded some of the more complicated types of contract have sometimes used terms which are misleading or conceptions which the business man has failed to understand; and in other cases they do not appear themselves to have understood the full implications of their proposals. To contractors who are anxious to co-operate with Departments to the full, this vagueness is a source of worry and irritation, while to others it provides loopholes for evasion, and in all cases causes an avoidable waste of time and money in complicated and unnecessary negotiations."6

The British use four types of adjusted price contracts ( $I$ ) cost plus a percentage, (2) cost plus a fixed profit (or management fee), (3) maximum price, (4) target cost (with a limit on payment of excess over the target). The Select Committee states that the two types of cost plus contracts "have no other merit than simplicity." And further:

"The Committee recognizes that in cases of urgency such types of agreement may be necessary; they also recognize simplicity as a characteristic of great importance. As to the maximum price contract they state it should be combined with a target cost; target cost contracts, they say, should be applied to 'novel products in their early stages before a fair fixed price can be set for straight-run production." "8

Britain, with a roo per cent excess profits tax, has no renegotiation statute. However, in connection with the various adjusted price contracts, "post costing" or "auditing" after production has been completed, in order to determine direct costs and allowance of overhead costs, is used.

As to such post costing the Committee reports:

"If prior estimation can be sufficiently close for the setting of a target cost or maximum price, post costing will be applied to determine the final price paid and the bonus, if any, earned by the contractor for keeping his costs below the target figure. When no estimate is possible, post costing provides no more than an independent assessment of direct costs and a check on the overheads allowable. But post costing should be used for the detailed information it can be made of to yield on the price structure of articles which are to be the subject of further contracts."9

E Fourth Report from the Parliamentary Select Committee on National Expenditure (Jan. 23, I94I).

'Id. at. 6.

${ }^{7} I d$. at 8.

${ }^{\text {IId. at } 9 .}$

${ }^{9}$ Id. at I5. 


\section{And the Committee further says:}

"The weaknesses of this system as now used lie partly in the types of contract to which it is applied ... partly in the impracticability of putting it into effective operation on a very large scale and partly in the failure of Departments to apply the system so as to produce a minimum of dislocation with a maximum of result." 10

\section{And again:}

"The vast numbers of contracts with a costing clause which have been, and are still being placed by the Ministry of Supply alone are well beyond what existing staffs could hope to keep abreast of if detailed costing is to be applied sufficiently rapidly to allow of use being made of the figures in placing further contracts or fixing prices. Apart from this, the delay, inconvenience and disturbance of production caused by full and detailed costing is in some cases considerable and is likely to increase as the supply and the standard of ability of additional cost accountants become less satisfactory.11

The absence of an over-all renegotiation act in Britain, with provision for recapture of profits, may have been the cause for this statement:

"The evidence indicates that all the cost investigator can do is to bring abnormally high costs to notice and, unless the firm changes its methods or something is done by the Department to improve the firm's efficiency, there is no reason to expect a reduction in future costs."12

On another phase of the "costing" problem, the Committee adds that:

"It has been stated on behalf of firms in contractual relations with more than one Ministry, or even with different branches of the same Ministry, that the costing methods employed may vary from department to department and that there may be cost investigators from two departments separately taking out figures for the same product ab initio, and without making adequate use of the firm's own accounts."13

In Britain, of course, there is an excess profits tax at the rate of roo per cent, and accordingly, to a large degree the question of rates of profit has not been so far to the front. Yet the Committee did make certain comments on profits. It regarded the proposal of "standard rates" and stated:

"It is recognized that in fixing any standard rates a number of variable factors must be taken into consideration in each case, such as whether the work is novel or repetitive, the rapidity of turnover, the proportion of subcontracting and the amount of assistance from public funds. But the elimination of unnecessary bargaining on each individual contract offers such important advantages that every effort should be made to arrive at standard rates calculated with reference to a fair return on capital employed."14

The suggestion had already been acted upon by the Costings branch of the Ministry of Supply which computes profit as a certain percentage of capital employed whenever a contract is "costed." And it was reported in the hearings of

${ }^{10} \mathrm{Id}$. at $15, \mathrm{x} 6$.

${ }^{11} \mathrm{Id}$. at 16.

${ }^{18} I d$. at $2 \mathrm{I}$.

${ }^{12} I d$, at 77 .

${ }^{14} I d$. at 22 . 
the Ways and Means Committee that more recently England is allowing $7 \frac{1}{2}$ per cent, before taxes, on invested capital. ${ }^{15}$

It is seen, following the arguments presented in the quotations from the Report, that Britain, having a certain amount of renegotiation in connection with many contract types and profits thereof, is still operating without renegotiation recapture of excessive profits. These are supposedly taken care of through the roo per cent excess profits tax.

In its recommendations, moreover, the Committee had this statement to make on the question of profits:

"Rates of profit should be related to capital employed; and that some degree of uniformity is highly desirable; but, since a simple fixed rate is hardly feasible, agreements to cover particular industries should be encouraged, though some flexibility should be retained to offer special incentives for special efforts."16

2. War Profits Control in Canada. The Canadians have not adopted over-all renegotiation as we know it. They have been the foremost promoters of the "target price contract." The development of the system was due, perhaps, to the fact that most items of munitions made in Canada were based on British prototypes. The Economist (London) in describing the system had this to say:

"Usually the price of the British manufacturer was converted into Canadian dollars. The Canadian contractor was allowed the target price-usually the British price plus a small profit-as a basis upon which to get into production on a portion of the initial contract, say to to 20 percent. The price was subject to audit. If manufacturing became more efficient and costs were found to be falling the contractor was allowed his costs plus profit-the prevailing profit has been $5 \%$. In addition, as an inducement to efficiency, he was allowed a percentage of the spread between the original target costs and his actual cost."17

This type of contract has been adopted in the United States and is used today by the Army to a considerable degree.

If the contract form is advantageous in Canada and works in the United States, it is quite possible that the future use of renegotiation can be considerably reduced.

3. War Profits Control in Germany. Under-Secretary Patterson's article on renegotiation ${ }^{18}$ dealt so authoritatively with German war contracts procedure that it has become a basic source for that phase of the world-wide government procurement problem. The Under Secretary first called attention to the fact that prices paid in Germany for war materiel are not set for each individual firm on the basis of its costs, but "are based in general on the costs of a group of suppliers and correspond to those of a representative producer within that group." Thus all manufacturers whose costs are within the lowest range are put in one group; other manufacturers with higher costs are classified in other groups. The prices are

\footnotetext{
${ }^{15}$ Hearings before Committee on Ways and Means, stlpra note 2, at 79.

${ }^{10}$ Fourth Report, supra note 5 , at 36.

${ }^{17}$ The Economist (London, September 5, I942) 303.

${ }^{28}$ Supra note 4, at II-I2.
} 
enforced as well as in the case of contracts previously made and contractors may not refuse to accept an order or delay delivery on the ground that the price is out of line. Manufacturers in the lowest cost group are given a reward through a provision that their profits will not be subject to the excess profits tax deductions. Such firms also are given favored treatment with respect to priorities for materials and labor. Firms not in this category are accordingly at a disadvantage. If contract orders are to be cut the higher cost firms will lose such orders first.

The power of the state under the German contracting system, it is seen, goes far beyond the mere question of excessive profits. Its main aim has been to keep production at a high level during the war. By so doing, and with the efficiency and reduction in costs forced by the war, German industry would be prepared, in the minds of German leaders, to enter foreign markets after the war.

The German contract and profit control system, it will be seen, is far more stringent than the renegotiation procedure which has been developed in the United States.

4. War Profits Control in Russia. "In the Soviet Union the land, industry, the banks and the transport system are state property, that is, belong to the whole people."19

In the light of the foregoing and in view of the well-nigh universal conception of the state ownership "of everything" in Soviet Russia, how is it possible to speak of war profits in that country?

An interesting article by John N. Hazard of the Division of Soviet Supply, Office of Lend-Lease, on Russian Government Corporations ${ }^{20}$ helps to bring to mind the fact that corporations do have profits in the Soviet Union. Thus, from profits a fund must be set up for improvement of workers' conditions. This sum is taken from the profits of the corporation at the rate of ro per cent.

In such corporations the administrative responsibility is in the hands of the director of the corporation.

"The director is held responsible under the criminal code if his enterprise produces goods which are below the standards set for the industry. Penalties for this offence have been increased since the outbreak of the present war to a term of from 5 to 8 years imprisonment." 21

But much of the procedure of business is similar to that prevailing in other economies. Written contracts are entered into for purchases and sales of materiel. These contracts often contain the conditions needed in working out the plans called for under the over-all economic planning of the state.

The profit and loss position of the corporations is reported frequently. Says the author referred to above:

\footnotetext{
${ }^{10}$ Jofre, Economic Planning in the U. S. S. R. (Foreign Languages Publishing House, Moscow, 1939) 8.

${ }^{20}$ Hazard, Soviet Government Corporations (1943) $4 \mathrm{I}$ MrcH. L. Rev. 850.

${ }^{21}$ Id. at 860 .
} 
"If the profit and loss statement of a corporation shows a loss when it is filed monthly and at the end of the year with the Commissariat of Finance to which the corporation is responsible and with the corporation's branch of the State Bank, as required by law, either of two conclusions may be drawn. The management has not come up to expectations or the planned prices are at fault. A review is made by the Commissariat to determine which is the cause. If the profits were larger than expected, either the management has proved more efficient than anticipated or prices were erroneously set. A review will likewise determine the cause. ... By introducing this state accounting system the government inaugurated a method of automatic control requiring inspection only in cases of unexpected variation from the anticipated result. It also introduced a record which management could affect by good or bad work and thus provided an incentive to greater personal effort." 22

World-wide Similarities. This brief survey of war profits control methods (other than taxation) used in four leading countries, reveals that irrespective of the economy prevailing in each country, profit control through contracts ( $I$ ) aims at reducing the cost of goods produced; (2) attempts to achieve this end either by setting definite cost limits prior to the contract or by post-auditing; (3) aims at assuring incentives, by providing some sort of bonus, premium or advantage, so that war materiel will be produced at a high level of output. All of them have an inescapable common denominator: they do interfere with the internal management of the business by compelling revelation of accounts and reports. What American proponents and opponents think of the system of profit control worked out in our renegotiation procedure is revealed in the following sections of this article.

\section{Arguments for Renegotiation}

The wrench to American conceptions of contract stability, to the ideal that legal processes should operate under law rather than men, brought about by renegotiation, is not minimized even by its proponents.

In opening his testimony before the Ways and Means Committee, the former chairman of the War Adjustment Board said:

"In my judgment as an individual, it (renegotiation) is a dangerous and un-American statute, but we are in a dangerous and destructive war which justifies unusual precautions and conditions."23

The Under Secretary of the Navy, speaking before the House Naval Affairs Committee, stated:

"Neither I, nor, I am sure, the Under Secretary of War, welcomes this task. It would be far simpler if we could leave the recovery of excessive earnings to some other agency or to an automatic machinery. That is the easiest path. But I could not in conscience say to you that I believe that there is any formula by which excess profits could be prevented on an over-all basis.

${ }^{39} I d$. at 866 .

${ }^{23}$ Hearings before Committee on Ways and Means, supra note 2, at 2. 
"Renegotiation is not a perfect solution any more than there is a perfect solution to war. It is too vast, and anyone who would undertake to say that the method used in dealing with this volume of business was the perfect one, I think wouldn't be competent to appear before your committee. There are no perfect answers. But this we believe is the nearest and the best that we have found to date."24

All the arguments in favor of renegotiation must hang on the central point: inordinate profits must be prevented in war time-but at the same time sufficient profits must remain to provide an incentive for efficient war material production.

The savings effected by the renegotiation procedure will no doubt be more fully treated in other articles in this publication.

In general, however, the savings have been effected (I) through recapture of excessive profits and (2) through reduction in prices to be paid for materiel on future delivery.

The total savings reported on September 9 th to the Ways and Means Committee by Mr. Karker was $\$ 3,955,845,000$. Of this sum recaptures accounted for $\$ 1,787,923,000$ and price reductions $\$ 2,167,922,000 .{ }^{25}$

These total savings were the result of 4,866 cases reviewed up to the end of July, 1943. These were not contracts, it should be remembered, but cases of various contractors some of whom may have held numerous government orders.

The examination of these cases revealed that about 40 per cent of the contracting companies had not made excessive profits. The excessive profits of the remaining 60 per cent of contractors ran about 16 to $161 / 2$ per cent of selling prices. On the total of contracts covered, the recoveries and the price reductions combined amounted to about to per cent of selling prices. Somewhere between 6 and 7 per cent of the contracting companies lost money on their production for war. ${ }^{20}$

What was the cost of this activity to the government? Estimated annual expenses of the War Department Price Adjustment Board were given as $\$ 3,522,300 ;{ }^{27}$ Navy Department expenses were estimated at $\$ 750,000{ }^{28}$ What may have been estimated or spent by other renegotiating agencies would probably not bring the total costs above $\$ 5,000,000$.

That renegotiation has resulted in substantial savings cannot be successfully denied. Later figures will no doubt show more economies.

The above savings might be reduced by deducting the amount which would have been collected through the excess profits tax. But in spite of that deduction, say its advocates, the ultimate savings would still be huge.

The proponents of renegotiation, over and beyond the savings to which they could point, were also of the opinion that renegotiation had not injured the financial position of the companies renegotiated. Thus one member of the Ways and Means Committee introduced a report showing effects of renegotiation on 28 cor-

24 Hearings before Committee on Naval Affairs, supra note $\mathrm{I}$ at $4 \mathrm{ro}, 4 \mathrm{xI}$.

${ }^{25}$ Hearings before Committee on Ways and Means, supra note 2, at 92, 93.

${ }^{28}$ Id. at 93, 94.

${ }^{28}$ Hearings before Committee on Naval Affairs, stupra note $\mathrm{r}$, at 449. 
porations; seven of these had not had their 1942 net earnings per share reduced by renegotiation, while numerous others had been reduced in earnings by comparatively small amounts per share. ${ }^{29}$

In addition, the Under Secretary of War called the Ways and Means Committee's attention to the fact that the Government had at its command certain other powers which it could have used in placing contracts which might have resulted in much more serious financial positions for contracting firms:

"He (the contractor) is in no worse condition than he would have been at the outset if we had not agreed upon a price and we had seen fit to place a mandatory order with him, because of the exigency of war, at a price of our own setting, and what we thought was a fair price. We do that largely today. It is necessary that we should do it, of course, for the conduct of the war." ${ }^{.30}$

In summary of the position of those defending renegotiation, it may be said that the procedure has resulted in savings; that in the over-all picture of business, while it has reduced some earnings, there is no instance given of a case in which a firm was forced to close its doors because of renegotiation. Finally, there remains the possibility that the government might have used the "mandatory order" procedure, and refrained from doing so, relying rather on the incentive of reasonable profit and the patriotic endeavor of the producer to make as much materiel as he possibly could.

When this is said, the main argument for renegotiation has been given. It is at this point that the difficulties of constitutionality, definite formulae for settlement, the right of appeal, etc., enter the picture. These are very serious objections, they go to the heart of the American way of life--they are the arguments against renegotiation.

\section{The Argument Against Renegotiation}

It has become almost traditional to lead off every presentation of reasons against renegotiation with a statement of its main fault: that it is a law not of principle but of men. While that is truly its great defect, let us first examine further the financial accomplishments of the law.

I. Savings effected by renegQtiation are not correctly stated in light of tax recoveries.

According to the estimate of the National City Bank of New York, 70 per cent of the total amount recovered would have been collected through the excess profits tax. ${ }^{81}$ The correctness of the estimate may be checked against the statement of the War Department's Price Adjustment Board's former Chairman, who stated before the House Naval Affairs Committee:

"The highest possible corporation tax for $194 \mathrm{I}$ was approximately 72 per cent. The maximum corporation tax for 1942 is 72.8 per cent on over-all earnings of $8 \mathrm{I}$ per cent on any increment of earnings, after the post-war credit. Thus so far as a corporation is

${ }^{20}$ Hearings before Committee on Ways and Means, sttpra note 2, at 889 .

so $1 d$. at 826 .

${ }^{81}$ Id. at 5 . 
concerned, the minimum difference between recovery in renegotiation and recovery under taxation is 27.2 per cent when the 80 per cent over-all rate is reached and rg per cent on any increment if the over-all rate is not reached. In many instances the difference is much greater."32

If the average figure of 70 per cent is used, then if, for example, a possible 9 billions of dollars might be saved by renegotiation $\$ 6,300,000,000$ would have been recaptured through taxes and renegotiation savings would have amounted to $\$ 2,700,000,000$. Such a sum, whether recovered through recapture of profits or by price reductions, is a saving which might be sufficient to overcome many objections.

2. Of purported savings through renegotiation, a large percentage would have been recovered through contract adjustments.

The base figure advanced by proponents of renegotiation of $\$ 3,955,840,000$ included price reductions in the amount of $\$ 2,167,922,000$. This is 54 per cent of the amount reported as recovered. Figuring this percentage on the sum of $\$ 2,700,000,000$ which could be saved in the example in the preceding paragraph only through the renegotiation statute, this would give total savings from price reduction of $\$ 1,45^{8,000,000}$. This saving might not otherwise be made since many earlier contracts did not contain price adjustment clauses.

Mr. Karker's figures may be checked with those later submitted by the Under Secretary of War. Reporting on figures for the War Department alone, as of the end of August, Mr. Patterson showed total adjustment of $\$ 2,949,000,000$ on some $\$ 28,100,000,000$ of approximate contract value. Recoveries amounted to $\$ \mathrm{r}, 399,900,000$ and price reductions to $\$ 1,549,100,000 .{ }^{83}$ Here again we have a figure of approximately to per cent in savings.

As against this saving and the cost to the government, which has been stated previously, business has claimed that the cost of renegotiation to it has been a heavy burden.

One of the members of the Ways and Means Committee said:

"I went into the office of one large cotton mill that is perhaps devoting less than 20 per cent of its full output to Government material, and they showed me a room in which they had four auditors and eighteen young ladies and men engaged in separating the cost items of this 20 per cent that went to the Government."34

During another day of the hearings, the following exchange took place:

"Mr. Knutson. I had a gentleman call on me the other day who is in the lumber business. He is connected with one of the larger companies. He told me that they had been put to an expense of about $\$ 3,000$, after which no renegotiation was had.

"Mr. Karker. They had a renegotiation and they presumably had a clearance. But he means he was not required to pay back anything.

${ }^{32}$ Hearings before Committee on Naval Affairs, sutpra note I, at 1000.

${ }^{38}$ Hearings before Committee on Ways and Means, stpra note 2, at 820 .

${ }^{34} I d$. at 86 r. 
"Mr. Knutson. Well, he was not required to pay back, and I am just wondering how much money it has cost American industry to prepare for such an ordeal, out of which nothing came in the way of return.

"Mr. Karker. Without question, Mr. Knutson, I think something came out of that, and I think his expenditure of $\$ 3,000$-assuming that figure is correct-was fairly modest expenditure under those circumstances."

The over-all cost to business, if the average renegotiation costs for preparation averaged $\$$ ro,000-some may have cost much less, others much more-might run as high as $\$ 50,000,000$.

But all in all, the conclusion seems inescapable that the cash recovery and price reductions brought about through renegotiation have been very substantial, and at a cost, both to government and business, which does not figure largely when the ultimate recoveries are borne in mind.

No, if renegotiation were to be discarded it would not be on the basis of its expensiveness or its failure to show worthwhile cash savings. It would be rather because of its damage to certain American principles and the possibility that there are other methods which would result in as large savings without violation of those principles.

3. Renegotiation does not operate on definite principles covering all cases. Under this objection come such arguments as "renegotiation is a method of men, not of law," "renegotiation does not deal equitably with various firms," "business does not know what to expect," "there is no over-all formula."

An illustration of the combination of these objections in the minds of business men appears in testimony given before the House Naval Affairs Committee by the Vice President of the General Electric Corporation:

"Mr. Maas. Mr. Rockey says he has no yardstick and he has no formula. He has a great many factors that are taken into consideration, but he can't tell us any formula for the weight that has to be given to each factor. Do you believe it is feasible or practicable to devise a formula, in general terms at least, upon which renegotiation would be based?

"Mr. Shreve. I don't think it is. I think that is one of the reasons renegotiation is not a good approach to the problem.

"Mr. Maas. What is there that so disturbs industry about renegotiation?

"Mr. Shreve. The uncertainty.

"Mr. Maas. The uncertainty of what will be allowed plus the time that it takes?

"Mr. Shreve. Right, and the length of time that the books have to remain open, really, before there is any degree of certainty as to what the financial performance of the company has been.

${ }^{30}$ Id. at 66. 
"Mr. Maas. Of course, your books remain open for a long time with the Treasury Department.

"Mr. Shreve. We have gotten used to that. This is another one on top of it."36

This testimony by an executive of one of the leading corporations of the country is repeated in varying terms by officers of other firms.

Speaking for the Johns-Mansville Corporation, ițs President, Mr. Lewis H. Brown, said:

"No manager can do any really intelligent planning of his financial future with these uncertainties pending. Nor do we in industry want to look forward to years of litigation and quarreling with our Government. ... American industry has done a magnificent job of producing the material of war. It has gladly subjected itself to higher tax rates and higher excess profits taxes than it has ever before experienced. If it is necessary to win the war we believe heavier taxes should be levied. If after all these taxes are levied there are profits left that are in fact excessive, then we believe some method such as the renegotiation law should be available to clear up the matter quickly and get it behind us." ${ }^{37}$

Perhaps the apogee of this feeling on the part of business with respect to the renegotiation procedure is found in the testimony of Mr. J. F. Lincoln, President of the Lincoln Electric Company, before the House Ways and Means Committee:

"I talked to you a lot about efficiency. I now want to talk about the last point, and that is the un-American law wherein five men can ruin any industry of this country, and where five men have already, in certain cases, laid the ground work for such ruin.

"I do not believe that the winning of this war is nearly so important as is the freedom of the individual in the United States. If we finish the war in the position which we are in now, in which the executive branch has the right, without recourse, to hold up to any individual the fact that he cannot do anything except at the behest of the Executive, then the United States, as a free country, is gone....

"Now, it is not important, relatively, whether we win this war. It is of outstanding importance whether we continue or ever do regain our liberty." 38

Mr. Robertson of the Committee, inquiring further into the statement of the witness "that it is not important relatively whether we win the war or not, and that our personal freedom at this time is of more importance than winning the war," received this answer:

"Mr. Lincoln. Mr. Robertson, I did not say that. I said this: that, relatively, it is more important that we retain our freedom than it is that we win the war. If we win the war and lose our freedom, we have made no advance over what would have occurred had we lost our freedom-which we would have done."39

Continuing the general objection against the renegotiation law, the president of a construction company had this to say:

${ }^{30}$ Hearings before Committee on Naval Affairs, supra note I, at 598 .

${ }^{37} \mathrm{Id}$. at $54 \mathrm{r}$.

${ }^{38}$ Hearings before Committee on Ways and Means, supra note 2, at 347.

${ }^{39}$ Id. at 348 . 
"We feel that the renegotiation law is thoroughly un-American and has no place on the statute books of this country. We believe an honest mistake was made by Congress in passing this law, as it did not realize what a destructive instrument had been placed in the hands of the Renegotiation Board. If the Congress feels that more money should be wrung from industry, why not get it over in one operation and increase the tax assessment against corporations, which are already at the breaking point." 40

Another witness had this to say:

"Since the Board can only renegotiate downward, the contractor knows that he comes in to get clipped. That is why they call the government agencies benzine boards in so many instances. When they are brought in, they know they are in for a cleaning."41

Renegotiation proceedings under the administration of thousands of government officials and contracting officers are, of course, subject to the personalities involved. Thus one witness before the Ways and Means Committee said:

"From there I will digress and state it is rather the method which has been taken by the people who came to renegotiate than the fact of renegotiation itself we object to.

"Now, when I attempted to tell the Major from the Department who came to see us I was told the problem we had to go through, he said it was irrelevant and had no bearing, that is your duty. We do not care to discuss it.

"So I said, "Very well, sir, we have nothing to say. You will have to do the talking and tell us the story and we will listen.'

"So we were told what we could have, what was due us, as partners, and I might say here that in the first year that these young men were organizing this business they were working for far less than they were able to earn in working for others, but with the thought of establishing a business for themselves, they made that contribution.

"As a matter of fact, two of them are married, and partly living on some of the earnings of their wives because we could not get the financial assistance other than I provided from personal funds, and it had to go back in the business to expand it.

"We have no complaint to make about that. We took the risk and we have made some money. Consequently we think we are entitled to some compensation for it, but it seems the officer in charge of renegotiation thinks our effort was net the consequencewhen I tried to stress the fact that in view of the fact that we had practically done all of this work on the basis of competitive bids and had therefore contended that our profits were due to efficiency and effort, we were told that was irrelevant also, that 'efficiency' should pay for 'inefficiency,' those words verbatim were said to me, and I desire to insert them in this record." 42

4. The renegotiation procedure fails to comply with fundamental legal principles.

When the Under Secretary of War presented his testimony to the Committee the total effect of complaints as to uncertainty, inequity, rule by men rather than law, came to a climax. Perhaps no better summary of all the pent-up feeling with respect to renegotiation can be found than the exchanges which took place between the Under Secretary and members of the Committee.
${ }^{s 0} I d$. at 386 .
${ }^{41}$ Id. at 43 I.
42 Id. at 952. 
Among the various points brought out during these exchanges were:

(a) The complaint that contractors renegotiated were not given "bills of particulars"a statement of the manner in which the renegotiation figure was arrived at;

(b) The problem of appeal to the courts for review of the settlement;

(c) Fear of reprisal;

(d) Lack of standards in renegotiation as compared with taxation.

a. Lack of bills of particulars. The Chairman of the Committee on Ways and Means, asked these important questions:

"The Chairman. If a contractor feels, Mr. Secretary, that he should not refund that which the Renegotiation Board, or those in control of the matters, call upon him to refund, and if they do not give him a bill of particulars, how is he to know whether he has any opportunity to go into court, or whether he should go into court, until he knows the contention of the government?

"Mr. Patterson. Well-

"The Chairman. If you say I owe you so much money, and I say I do not, and if you do not accept what I say I owe you, then I think you should be able to show some reason why I owe you the amount you say I owe you. That is, I think we should be able, without any prejudice either way, to have some tribunal determine it, to take it into court, where the court can get all the facts. If that were done it seems to me the contractor might very often, if the Government would show him where he owed so much money, be satisfied."

"Mr. Patterson. I doubt if the court would tell him, at the end of a complete breakdown that his cost or his profits should be reduced so much, I doubt it; some might.

"The Chariman. Do you feel in that respect, under your procedure now, that it is as fair to the contractor as it is to Government?

"Mr. Patterson. I believe it is. Suppose, for instance, a contractor has made $\$ 60,000,000$ profit in a year, and we believe that under all the circumstances, and taking into account everything he presses on us, $\$ 30,000,000$ is enough, but he should make us give him the reason, and break it down, and say, for the risk involved, $\$ 9,900,000$, and for the extra services required, so much-I do not think it is possible to do that.

"The Chairman. How can you come to a conclusion yourself, if you do not break it down in your own mind? You must have an idea about it yourselves. How can you come to a conclusion unless you break it down and know why he owes so much money? "Mr. Patterson. I think all you can do in that case is to figure out, at the time he took over the contract, how much you would have allowed him as a contract price." ${ }^{33}$

On the same point of a bill of particulars, Mr. Disney of the Committee took up a line of questioning, referring to a previous contractor-witness:

"Mr. Disney ... who (the contractor) said that he was told by the Atlanta office, when he asked for a statement of reasons and facts upon which the decision was based, that your organization could not furnish them to him because that was 'secret criteria.' ... Pursuing that a little further, under the statute, you are not required, in making a decision as to what are excessive profits, to give the reasons for your decision, are you?

${ }^{43}$ Id. at 825. 
"Mr. Patterson. No, not under the statute, and I do not believe you could give any analysis. You can talk and talk and talk about it. But when it comes down to the final pinch, what you say is, 'Well, in view of all these factors, I think a profit of $\$ 1,000,000$ is too much on this job and $\$ 500,000$ would be enough; based upon all my. experience and all the factors of the case, and everything.' Then if he says, 'Why just tell me which factors make it unreasonbale,' and so forth, you know very well that that cannot be done in all cases; it just cannot be done.

"Mr. Disney. I do not know it, and I never heard of an American court that could not give a reason for his decision; and he is required to. In nearly all jurisdictions, he is required to set out a statement of facts and his conclusions of law." 44

As can be seen from the foregoing excerpts of testimony, repeated questioning and answers to such questioning, brought no admission that a detailed bill of particulars could be given to contractors. The reason for the insistence on such a bill moved rapidly into a consideration of the next main problem handled by Mr. Patterson.

\section{b. Appeal to the courts for review of the settlement.}

After the last statement quoted from Mr. Disney, the Under Secretary replied:

"Mr. Patterson. Yes, and when it is all said and done, after he (the Court) has done all of that, he says down at the end, 'I therefore find the plaintiff in the sum of so much.'

"Mr. Disney. Yes; but the litigant has something to appeal on.

"Mr. Patterson. But if the litigant then comes in and says, "Just tell how much did you allow for this and for this and for this,' the judge tells him to go chase himself.

"Mr. Disney. Judge, I am surprised at you, I really am surprised at you; in fact, I am astonished; I am astounded. ${ }^{45}$

"Mr. Patterson. You cannot possibly attribute one dollar of value to every single factor in every single case, and put a dollar tag on it and say, 'This is \$ro and this is \$20.' That is what I mean by saying that."

A few moments later Mr. Disney asked these questions:

"Mr. Disney. I am trying to discuss this with you as two lawyers. If we were judges on the Court of Claims, and we take a look at this statute, we would want to know what standards formed the basis for the action of the executive department, or the War Department, would we not? If there were no standards, we would at once, as you said awhile ago, tell the litigant to go and chase himself, because there would be no means except a trial de novo to determine the application of the law, would there?

"Mr. Patterson. Well, I did not say the judge would tell them to go chase themselves. I said that if he made an unreasonable demand and opposite each finding or conclusion put a dollar sign, I think the judge would tell them that, and so he would."46

Prior to Mr. Disney's questions, Mr. Jenkins, also of the Committee, had said: “. . . And let me say this, and see if I am not right about this. You also gave the impression that a man had easy access to the court.
"Id. at 844 .
${ }^{45} \mathrm{Id}$. at 844,845 .
${ }^{18}$ Id. at 845,846 . 
"The testimony before us, and the overwhelming testimony, I think the unanimous testimony, was that it is impractical to get into court in these cases. Do you know of any case that ever got into court?

"Mr. Patterson. No, I do not know of any case where they finally failed to arrive at a mutual agreement. Several were headed the other way, but the only ones that have come before me have had a mutual agreement.

'Mr. Jenkins. When you say 'mutual' agreement, that would imply an agreement with full accord; but you will not admit that there has ever been any coercion at all?

"Mr. Patterson. No; there is no coercion. ...

"Mr. Jenkins. I am very sorry I voted for that law with all those things in it. I am very sorry that $I$ voted for that bill when it gave you full and final determination.

"Mr. Patterson. Subject to court review, of course.

"Mr. Jenkins. That is the point; but how do you get into court?

"Mr. Patterson. They can find their way into the courthouse, all right.

"Mr. Jenkins. I asked I suppose one of the best and most widely experienced lawyers in that line of business in this country, and he has not been able to get into court. So, so long as you take the attitude, Mr. Secretary-you and your board-that you are right and will not yield, then I want to say to you that you are making a grand mistake.

"Mr. Patterson. The only question is whether we have not been too easy on contractors."

Here the excerpts on this problem have reached an impasse. On the one side an insistence on the right to review; on the other side an insistence that there is such a right. It is to be noted that the Lincoln Electric Company may perhaps furnish the first instance of resort to courts, since it has definitely refused the settlement offered on renegotiation of its Navy Contracts. ${ }^{48}$

However, Mr. Patterson stoutly maintained his position in response to questions from Mr. Reed of the Committee.

"Mr. Patterson. I will bet you that when they (contract cases) get into court, if any of them take a case to court, any of the cases we have closed, there will not be a single dollar recovered by them.

"Mr. Reed. Of course not; we know that.

"Mr. Patterson. Because any court would say that the allowance made was a fair and reasonable profit on the business done.

"Mr. Reed. They would be bound to, because those are the findings of fact, so that these men cannot get any relief.

"Mr. Patterson. I am satisfied that that would be the common public opinion too."40

"Id. at 837,838 .

${ }^{18}$ N. Y. Times, Oct. 21, 1943, p. 34 , col. 4 .

${ }^{6}$ Hearings before Committee on. Ways and Means, supra note 2, at 839. 
c. Fear of Reprisal.

Rather than go into specific instances of complaint from business, excerpts will be given from statements by various members of the Ways and Means Committee.

Mr. Jenkins had this to say:

"But I want to say to you that I dare say it will be the unanimous experience of the members of this committee-perhaps I am going too far; perhaps it should be only go per cent of the members of this committee-that everybody with whom they have talked, who has been renegotiated, has been dissatisfied.

"One Congressman appeared before us here the other day and said that he had been entertained by 86, I think it was, in his community, and each and every one of them had told him to be sure and not come back to Washington and give the names of any one. I know that every person I have talked with-and I have talked with dozens of themhave told me that I must not mention any names, and that they must not come to Washington."

\section{Mr. Knutson of the Committee said:}

"Again I have a peculiar case in mind, and unfortunately I am not at liberty to name the company because of their fear as to what might happen to them if it be found out that they had been contacting members up here on the Hill.

"Mr. Karker. That is a very unfortunate inference to leave in the record.

"Mr. Knutson. It is unfortunate, but nevertheless it is the situation. We know it. No one can fight the Government. You have the Internal Revenue; you have the Wage and Hour Division; the Social Security Division; and all these other organizations who can at least make life miserable for any one who would not want to go along." 51

While Mr. Carlson said:

"I think there is a definite fear of reprisal on the part of some of these contractors as to what might happen if they take the matter up with Members of Congress, or appear before the Committee in these hearings. Do you definitely state, to your knowledge, that there are no threats of reprisals or that there will be none?

"Mr. Karker. Certainly I, speaking for myself, can say that there has been none, there is none, and there will be none. I think I can speak with equal certainty for the men engaged in renegotiation in the War Department, and by inference, because I know the character of the men who are engaged in this job in other departments, I think I can speak for them. But there are bound to be exceptions. I do not know what they are or where they will arise, but I think the fear is in much greater volume than the justification." 2

As in the previous discussion of the lack of bills of particulars and access to the courts, one side insisted as sharply as the other that the alleged deficiencies in renegotiation procedure ought not to exist, and did not exist. But, that there is some reason to believe that these difficulties are present cannot, in the main, be denied.

$$
{ }^{50} I d . \text { at } 836 . \quad 57 \text { sd. at } 68 . \quad{ }^{52} I d . \text { at } 78 .
$$


d. Lack of Standards Comparable to Tax Procedure. The ideas of the propounders of the questions addressed to the Under Secretary on this point border on the proposition that taxation might be as efficient a method of recovering excessive profits as renegotiation, and less fraught with the dangers of uncertainty, inequities, duplication of effort, and so on.

One portion of the questioning again centered on the lack of standards in renegotiation, went in to the possibilities of a delegation of the legislative power without any standards. Mr. Disney asked the following questions:

"Mr. Disney. If we should attempt to delegate our power to tax which is lodged here and no place else, we would have to do it with standards for the courts to construe, would we not?

"Mr. Patterson. Yes.

"Mr. Disney. Just as in the 'sick chicken case,' the courts upset the N.R.A. because we had tried to delegate legislative power without any standards.

"Mr. Patterson. This could not stand as a taxing act. There is no doubt about that. It is too broad and too general.

"Mr. Disney. Then, if it is an indirect delegation of power to tax, it is unconstitutional, is it not?

"Mr. Patterson. That is an academic question, Mr. Disney, because no one could read the act and possibly think it was a taxing act."

A short time later Mr. Disney inquired:

"This statute is almost as broad as the Congress writing a letter to the War Department and saying, 'Go to it and collect the excessive profits in any manner that you see fit and to the extent you see fit'-is it not, unless there are standards to guide you?

"Mr. Patterson. Well, there are no standards in it except the standard that it shall be fair and just, and I do not know what else you could do....

"I do hope there will be no effort made, though, to write into the law a lot of conditions and restrictions and provisos and standards, and so on, because I am afraid it will be unworkable if we do.

"Mr. Disney. Well the excessive-profit tax statute is not unworkable, is it?

"Mr. Patterson. No, it is not unworkable.

"Mr. Disney. It is not sufficient to meet this situation; is that your judgment?

"Mr. Patterson. Well, I do not use it as a taxing statute. It is far more like the mandatory order statute.

"Mr. Disney. You figure the excessive-profits statute does not go far enough and take the exorbitant profits. If it did, there would be no necessity for recapture, would there, if the excessive-profits statute were broad enough?

"Mr. Patterson. Yes; I agree with you."54

${ }^{53}$ Id. at 848 .

${ }^{54} I d$. at $850,85 x$. 
It might be interesting to go into other objections which were raised by the House Ways and Means Committee and the House Naval Affairs Committee. Thus a number of questions were asked on co-ordination between the various price adjustment boards; whether or not in renegotiation the renegotiators had in mind the non-governmental sales of contractors as well as their governmental sales; inequalities of amounts left with contractors who were in the same line of business; qualifications of the renegotiating officials; the much discussed point of renegotiation before or after taxes; the bilateral or unilateral character of renegotiation.

However, as will be seen in the summary which follows this section, the heart of the pro-and-con of renegotiation is mainly centered around the points which have been presented here through the words of committee members and witnesses.

\section{Striking a Balance}

Is it possible to evaluate the arguments for and against renegotiation and come away with a debit or credit balance?

After reading the colloquies which have been quoted, one outstanding impression remains: they were replete with what semanticists term "emotional referants." Time and again the innate and perhaps unconscious prejudices of committee members, and witnesses, came to the surface. When the heat of argument is removed from these colloquies what remains to aid us in forming a final opinion on renegotiation?

To come to any abiding conclusion, it will be necessary to center all contentions under one point, on both the pro and con sides of the discussion.

On the affirmative side we have one word: War.

On the negative side another word: Constitutionalism.

And topping all other considerations is one point: Winning of the war.

The opponents of renegotiation admit this as readily as its proponents-but they insist that the war must be won under constitutional conditions.

What are the subsidiary arguments on both sides?

I. Proponents say that the war must be won with the utmost of economy; that renegotiation achieves this result since it is able to get at excessive profits which might be lost even with the use of a remodeled excess-profits tax. They claim that renegotiation gets the money back now when it is needed, and avoids long-drawn out litigation. They assert that by very reason of the lack of set standards and bills of particulars they are able to reward efficiency, low-cost production, speed in production; that renegotiation results in the collection of a body of data which enables the government to obtain more favorable prices.

Stripping the testimony of its emotional referants, it is clear that renegotiation has saved tremendous sums of money, even after giving due credit for sums which may otherwise be recovered through the excess profits tax.

It is true that renegotiation recovers the money now. 
Through the use of the factors set forth in the Joint Statement the price adjustment boards have been able to reward efficiency, low-cost production, speed in production, novelty in production. The contracting officers, with the body of data which has been secured through renegotiation are in possession of information which aids them in procuring additional material at lower prices.

On the material side of the picture, the dollars and cents side, renegotiation has fulfilled an important mission, it has performed a job which might otherwise have gone undone.

2. The opponents of renegotiation, when in turn their statements are stripped of words of emotional content, are returned almost entirely to their arguments against its unconstitutional aspects; its "un-American" features; instances of alleged injustice; claims that the contractor is not provided with a day in court; that war production is hindered by diverting attention of producers from the main job of producing; that the contractor is not informed of the standards by which his profits are judged; that the recapture of profits leaves contractors in a dangerously weakened condition financially.

It must be admitted that in normal times such procedure as renegotiation would not be usable-there would in the first place be no reason for it. And the chief danger of the renegotiation process may be the possibility that it would become an entering wedge for further interference in private business in time of peace.

What is lost sight of is the fact that in time of war even more sacred constitutional liberties than that of freedom of profits may have to be infringed. Lincoln, during the Civil War, as is well known, suspended the right of habeas corpus. During the last war and this, men have been taken from their personal careers and drafted into the armed forces. Censorship, of one type or another, has been imposed.

That there are instances, perhaps numerous ones, where inequity has resulted, that business may to some extent be fearful of "reprisals"; that there are features of the renegotiation statute which should and doubtless will be changed, must be admitted. That to some degree production may have been slowed down, may also be true.

But if the cost of war should be held to a minimum (and there is no disagreement on that proposition) some means of doing it had to be used. In the United States it was the renegotiation statute.

Perhaps the "constitutionalists" should have been more vocal in their disagreement at the time the act was proposed. They were previously threatened with an over-all 6 per cent profit limitation act-to this there was sturdy opposition at the time. Yet, ironically enough, examination of the figures on recovery of excessive profits shows that the average profit left the contractor under renegotiation has been about 6 per cent. If the principle of constitutionalism was worth fighting for, it should have been defended at the time the 6 per cent limitation was proposed.

Whether or not devotion to principle or the exigencies of expense in fighting a great war, or their combination, resulted in the British excess profits tax of 100 
per cent is not to be discovered at this point. 'However, the Select Committee's report, ${ }^{55}$ referred to earlier in this article, had this to say:

"It has been argued that the introduction of an Excess Profits Tax at the rate of roo per cent makes insistence on the form of contract relatively unimportant. Further, it has been stated that this rate of tax has removed the incentive to cheap production, even from a fixed price contract. This latter argument, though not entirely correct, is supported by evidence, and has considerable weight since it is true that no contractor stands to gain by an increase in his profits above the pre-war standard. It is outside the scope of the Committee's inquiry to consider the reasons for the imposition of the Excess Profits Tax; but the Sub-Committee emphasize that cheap production is vital to the successful prosecution of the war."

In addition to the British roo per cent excess profits tax the contractor is also specifically limited, at present, to $7 \frac{1 / 2}{2}$ per cent profit on his contract.

So that despite fears as to the lack of incentives to cheap production, the recapture of excessive profits has also gone on in Britain. And to a certain extent, Britain has a considerable amount of renegotiation, although there it is termed "post-costing" and takes place in specific contracts.

The final conclusion must be:

War is a known economic, physical, spiritual evil. During war each and every element of the community must bear its share of the hardships. To some this is brought home by actual fighting, wounds and death. To others it must mean separation, disturbance of careers, broken plans. Business has to bear its share as well. Its share is not only increased and sometimes difficult production problems, uncertainty as to the future, but also a certain and unpleasant amount of interference with its daily processes.

The inequities of renegotiation are being carefully considered. That there will be amendments to the statute, and that there will be changes in procedure, need not be doubted; witness the proposals of the now pending Revenue Bill of 1943 .

Once the changes are in effect, most of the damage of renegotiation will have been corrected, except those to injured feelings and, in a few instances, true, to profits which might have been "rosier" except for renegotiation.

That large sections of American business have been so insistent in their opposition to renegotiation is all to the good. We can never have too many, nor too active, opponents of undue governmental interference. Let us hope that representatives of business will continue as alert in their defense of a proper balance of "true liberties" during the days of peace; that in future normal times there will again be the freedom of all types which the war has interrupted.

For business men who will have felt that their efforts, their long hours, and their successes in producing for war, have been unappreciated; who have flown "E" pennants from their flag-staffs while renegotiation officers were, they felt, failing to give all consideration to their efforts, there remains, in addition to a

\footnotetext{
${ }^{05}$ Supra note 5 , at 21 .
} 
conviction that renegotiation is un-American, the fact that renegotiation achieved by its much-disliked procedure may some day afford business its greatest comfort.

This possibility was best expressed by the Under Secretary of War at one stage of the Ways and Means Hearing, when, after a long and difficult line of questioning, he said:

"Mr. Jenkins, I will venture a prediction, if I may. That is, that after the war is over and everything is done, there will be a clamor in this country that there was profiteering during the war in spite of renegotiation; and this statute is simply designed to prevent profiteering and a crop of war millionaires." 50

In that evil day, should it come, businesses which were renegotiated, and particularly where the process was difficult, thorough and unpleasant, will have these proceedings and their settlement agreements to which to point. They may then be happy that they were renegotiated. Because of that procedure they may use the opening words of an old song: "Integer vitae scelerisque purus."

It is to be remembered that true economy in waging a war will redound to the benefit of everyone. Especially is this true in a democracy. One of the profoundest thinkers on problems of statecraft in a chapter entitled "On Liberality and Parsimony" had this to say of state expenditures:

"Since, then, a prince cannot without harming himself practice this virtue of liberality to such an extent that it will be recognized; he will, if he is prudent, not care about being called stingy. As time goes on he will be thought more and more liberal, for the people will see that because of his economy his income is enough for him, that he can defend himself from those who make war against him and that he can enter upon undertakings without burdening his people. Such a prince is in the end liberal to all those from whom he takes nothing, and they are numerous; he is stingy to those to whom he does not give, and they are few."

With proper reforms the renegotiation of contracts will secure this desired end for the American people.

${ }^{50}$ Hearings before Committee on Ways and Means, supra note 2, at 837.

${ }^{57}$ Machanelis, The Prince and Other Works (Univ. Classics ed. I941) 143. 